\title{
Dicarboxylic Amino Acid Uptake in Normal, Friedreich's Ataxia, and Dicarboxylic Aminoaciduria Fibroblasts
}

\author{
S. B. MELANCON, B. GRENIER, L. DALLAIRE, M. POTIER, G. FONTAINE, B.GRIGNON, G. GEOFFROY, B. LEMIEUX AND A. BARBEAU
}

SUMMARY: Glutamic and aspartic acid uptake was measured in skin fibroblasts from patients with Friedreich's Ataxia, dicarboxylic aminoaciduria, and normal individuals. The results showed no difference in uptake kinetics of either dicarboxylic amino acids between Friedreich's Ataxia and normal cells, but reduced uptake velocities in dicarboxylic aminoaciduria fibroblasts. Friedreich's Ataxia fibroblasts were, however, less calciumdependant and more magnesium and phosphate-dependent than controls in glucose-free incubation mixture. This difference might be related to some degree of glucose intolerance by' Friedreich's Ataxia fibroblasts in culture.

RÉSUMÉ: L'incorporation de l'acide glutamique et aspartique a été mesurée dans les fibroblastes cutanés de patients souffrant d'Ataxie de Friedreich, d'aminoacidurie dicarboxylique et de témoins normaux. Les résultats démontrèrent une cinétique normale de l'incorporation des deux acides aminés étudiés dans les fibroblastes d'Ataxiques et une vélocité d'incorporation réduite dans l'aminoacidurie dicarboxylique. Les fibroblastes d'ataxiques se montrèrent différents des contrôles normaux et pathologiques dans leur régulation ionique et glycolytique. Ces différences peuvent être reliées à une utilisation réduite du glucose par les cellules ataxiques en culture.

From le Centre de Recherche Pédiatrique de l'Hôpital Ste-Justine, 'Montréal, l'Institut de $\mathrm{Re}$ cherches Cliniques de Montréal, le Centre Hospitalier Universitaire de Sherbrooke

Reprint requests for the complete supplement on Friedreich's Ataxia (Phase Two, Part Two) to:

Dr. André Barbeau, M.D., Clinical Research Institute of Montreal, 110 Pine Avenue West, Montreal, Quebec, Canada, H2W IR7.

\section{INTRODUCTION}

Recent studies of amino acid levels in Friedreich's Ataxia have demonstrated a possible dicarboxylic and $\beta$-amino acids conservation defect (Lemieux et al., 1976). Although reduced CSF taurine and aspartic acid levels could have been explained on the basis of technical interference during automatic analysis of small concentrated samples (Lemieux et al., 1978), there remained an apparent renal conservation defect for taurine, aspartic acid, and $\beta$-alanine. Further information was provided by the finding of reduced aspartic acid levels in the retina, and reduced glutamic acid and taurine levels in the cerebellum of 3-acetyl pyridine injected ataxic rats (Butterworth et al., 1978 a). Decreased levels of aspartic acid were also found in cerebellum of rats rendered diabetic by Alloxan monohydrate injections (Butterworth et al., 1978 b). These findings suggested that the alterations in amino acid concentrations observed in tissues and biological fluids of patients with Friedreich's and other ataxias might be secondary to changes in membrane composition or permeability (Barbeau, 1978).

The present investigation was designed to assess amino acid transport in cultured skin fibroblasts from patients with Friedreich's Ataxia. Although the transport properties of cultured human diploid fibroblasts have not been well characterized, there have been a few investigations showing the presence in fibroblasts of group-specific amino acid transport systems corresponding to the major systems found in other mammalian tissues (Groth and Rosenberg, 1972; Hillman and Otto, 1974; Booth and Nadler, 1975; Kaye and Nadler, 1976; Pellefigue et al., 1976; Revsin and Morrow, 1976). Since it was not ethically acceptable to proceed to transport experiments using kidney needle aspirates from patients with Friedreich's Ataxia, in whom a renal defect is only suspected, we have initiated a study of dicarboxylic amino acid transport using cultured skin fibroblasts. The present investigation was conducted using two sets of controls for the Friedreich's Ataxia fibroblasts; (a) fibroblasts from age-matched normal individuals and (b) from younger subjects with a known familial dicarboxylic amino acids renal conservation defect (Melançon et al., 1977).

The finding of altered dicarboxylic amino acids transport parameters in both Friedreich Ataxia and dicarboxylic a minoaciduria subjects would lead to the recognition of a genetic membrane defect involving the conservation of amino acids rather than changes in membrane permeability secondary to an unknown disease process.

\section{METHOD}

Skin biopsies were obtained with informed consent from 5 patients with Friedreich's Ataxia (FA), 5 individuals with dicarboxylic aminoaciduria (DCA), and 13 control subjects. Fibroblasts were cultured in minimum essential medium (MEM Eagle) with Earle's salts and L-glutamine (GIBCO) supplemented with $10 \%$ fetal calf serum, $100 \mathrm{U} / \mathrm{ml}$ penicillin, $100 \mu \mathrm{g} / \mathrm{ml}$ streptomycin, and $250 \mu \mathrm{g} / \mathrm{ml}$ Fungizone at $37^{\circ}$ in $5 \% \mathrm{CO}_{2}, 95 \%$ air. The fibroblasts were harvested at confluency using $0.25 \%$ trypsin in Hank's balanced salt solution. All amino acid uptake experiments were performed 
on cells between their 7th and 20th passage. For uptake experiments, confluent fibroblasts from one $75 \mathrm{~cm}^{2}$ tissue culture flask (Corning) were trypsinized and suspended in $20 \mathrm{ml}$ nutrient mixture. Half of the suspended cells were seeded evenly over 14 size $9 \times 50 \mathrm{~mm}$ glass coverslips (Belko Glass inc) in a $100 \mathrm{~cm}^{2}$ square tissue culture dish while the remaining cells were grown back to confluency in the original flask. Twenty-four hours after plating, the micro-coverslips containing flask was fed with MEM containing $10 \%$ fetal calf serum without antibiotics. Forty-eight hours later, the coverslips were mounted on a stainless steel rack which holds ten coverslips side by side in a vertical position and permits simultaneous and identical manipulation procedures. The coverslips were immersed $3 \times 10 \mathrm{sec}$. in Dulbecco's phosphate buffered saline (PBS) and preincubated for $15 \mathrm{~min}$ in PBS containing $0.1 \%$ glucose (PBSG). Amino acid uptake was measured using uniformly labeled L-aspartic- ${ }^{14} \mathrm{C}$ and L-glutamic-14 $\mathrm{C}$ acids (New England Nuclear) and unlabeled substrates at the indicated concentrations in PBSG at $37^{\circ}$ (unless stated otherwise). The radiochemicals were subjected to two-dimensional ascending paper chromatography (Perry et al., 1975) and autoradiography and found to contain less than $1 \%$ contamination by $\alpha$-alanine, threonine, serine and glutamic acid (in Laspartic- ${ }^{14} \mathrm{C}$ acid) and less than $0.5 \%$ contamination by pyrolidone-5carboxylic acid, $\gamma$-amino-butyric acid and aspartic acid (in L-glutamic$\left.{ }^{14} \mathrm{Cacid}\right)$. This low order of contamination, being rendered negligible by further dilution in non-radioactive amino acid solutions, was not taken into consideration.

The incubation medium consisted of PBSG to which the labeled amino acids were added with or without the test compounds. Incubation proceeded at $37^{\circ}$ in $15 \mathrm{ml}$ stainless steel waterbaths. Individual coverslips or the whole rack were taken out at the appropriate time and immersed successively in 3 beakers containing ice cold PBSG, touched to an absorbent paper towel, and placed in a test tube containing $1 \mathrm{ml}$ of $0.1 \mathrm{~N} \mathrm{NaOH}$. The test tubes were mixed at high speed on a vortex mixer and shaken overnight at $37^{\circ}$ in a water-bath. Aliquots of 0.5 $\mathrm{ml}$ were then taken for protein determination by the method of Lowry (1951) and liquid scintillation counting in $10 \mathrm{ml}$ of Aquasol (New England Nuclear) in a Packard Tricarb model 3375 liquid scintillation counter. Radioactivity of the cells was corrected for protein value of each individual coverslip and a blank value corresponding to the radioactivity absorbed during a one second immersion of duplicate coverslips from each cell line into the incubation medium, as above. Radioactivity of the substrate solution was measured prior to incubation and was used to calculate the amino acid incorporation into fibroblasts. Uptake of L-aspartic and L-glutamic acid was expressed in $\mathrm{nmol} / \mathrm{min} / \mathrm{mg}$ cell protein.

The kinetics of aspartic and glutamic acid uptake were determined

\section{TABLE I}

Composition of Buffers for Amino Acid Uptake Experiments in Cultured Human Skin Fibroblasts

\begin{tabular}{|c|c|c|c|c|c|c|}
\hline \multirow[t]{2}{*}{ Buffer } & \multicolumn{6}{|c|}{ Ions (mM) } \\
\hline & {$[\mathrm{Na}]$} & {$[\mathbf{K}]$} & {$[\mathbf{M g}]$} & [Ca] & {$[\mathbf{C} 1]$} & {$\left[\mathbf{P O}_{4}\right]$} \\
\hline PBS* & 164 & 4.0 & .49 & .85 & 149 & 13 \\
\hline $\mathrm{Na}$ free & $1 \dagger$ & 3.8 & .47 & .85 & 142 & 13 \\
\hline $\mathrm{Na} 10 \mathrm{mM}$ & 10 & 3.7 & .65 & ND & 149 & 20 \\
\hline $\mathrm{Na} 50 \mathrm{mM}$ & 46 & 3.7 & .65 & ND & 150 & 21 \\
\hline $\mathrm{Na} 100 \mathrm{mM}$ & 94 & 3.9 & .66 & ND & 139 & 21 \\
\hline $\mathrm{Na} 50, \mathrm{~K} 100 \mathrm{mM}$ & 50 & 100 & .69 & ND & 147 & 21 \\
\hline $\mathrm{Mg}$ free & 155 & 4.1 & $.05 \dagger$ & .9 & 143 & 13 \\
\hline Ca free & 153 & 4.2 & .49 & $.05 \dagger$ & 142 & 13 \\
\hline $\mathbf{K}$ free & 157 & $0.1 \dagger$ & .48 & .9 & 142 & 14 \\
\hline \multirow[t]{2}{*}{ Tris- $\mathrm{P0}_{4}$ free* } & 155 & 4.0 & .48 & .5 & 164 & 0 \\
\hline & {$[\mathrm{Na}]$} & {$[\mathbf{K}]$} & {$[\mathbf{M g}]$} & [Ca] & {$[\mathbf{C} 1]$} & {$\left[\mathrm{PO}_{4}\right]$} \\
\hline PBSG* & 160 & 4.3 & .58 & .86 & 151 & 13 \\
\hline $\mathrm{Na}$ free & 2 & 3.7 & .54 & .68 & 142 & 19 \\
\hline $\mathrm{Na} 10 \mathrm{mM}$ & 11 & 3.7 & .55 & .68 & 149 & 19 \\
\hline $\mathrm{Na} 50 \mathrm{mM}$ & 48 & 3.8 & .56 & .52 & 149 & 19 \\
\hline $\mathrm{Na} 100 \mathrm{mM}$ & 96 & 4.0 & .55 & .62 & 142 & 21 \\
\hline $\mathrm{Na} 50, \mathrm{~K} 100 \mathrm{mM}$ & 52 & 95 & .57 & .42 & 151 & 21 \\
\hline $\mathrm{Mg}$ free & 156 & 4.2 & .07 & .70 & 146 & 13 \\
\hline $\mathrm{Ca}$ free & 153 & 4.4 & .54 & .04 & 144 & 13 \\
\hline $\mathrm{K}$ free & 155 & 0.1 & .55 & .73 & 143 & 13 \\
\hline Tris-G-P $0_{4}$ free* & 153 & 4.4 & .61 & .89 & 168 & 0.1 \\
\hline
\end{tabular}

* PBS: phosphate buffered saline pH 7.5 without glucose

Tris- $\mathrm{PO}_{4}$ free: phosphate replaced by equimolar tris (hydroxymethyl) aminomethane PBSG and Tris-G contained glucose $100 \mathrm{mg} / \mathrm{l}$

+ Cations replaced by equimolar amounts of lithium. ND:not determined 
Inhibition studies by membrane active chemicals and competitor amino acids and drugs were performed at the indicated concentrations of test compounds after a $15 \mathrm{~min}$ preincubation. The test compounds were obtained from Sigma Chemical Co. and Calbiochem. Oxidation of glutamic acid was studied by measuring the ${ }^{14} \mathrm{CO}_{2}$ trapped in suspended plastic wells (Kontes Glass co.) filled with $0.1 \mathrm{ml}$ of $0.1 \mathrm{~N} \mathrm{KOH}$ in glass wool, using fibroblast layered coverslips placed cell up, in a glass culture tube (Belko) containing 0.025 $\mathrm{mM}$ L-glutamic acid $(0.25 \mu \mathrm{Ci})$ in $1 \mathrm{ml}$ PBS at $37^{\circ}$ for $15 \mathrm{~min}$. At the end of the incubation period, the plastic wells were dropped in liquid scintillation vials containing $10 \mathrm{ml}$ of Aquasol and counted for radioactivity. For calculation of oxidation rate, the amount of radioactivity in the wells was compared to the radioactivity in the incubation medium, after correction for the amount of protein on the coverslips and a blank value obtained by incubating cell-free coverslips as above. These results were expressed in pmol. glutamic acid oxidized per min. per mg cell protein. The statistical analyses were carried out using Student's t-test and values of $1 / 2.05$ were retained.

\section{RESULTS}

\section{Time course (fig 1)}

The uptake of aspartic (Asp) and glutamic (Glu) was linear with increasing protein content from 5 to $100 \mu \mathrm{g}$ per coverslip and linear with time up to $90 \mathrm{~min}$. at $0.01 \mathrm{mM}$ substrate concentrations. Previous experiments using dicarboxylic amino acids disappearance rates from incubation medium (Melançon et al., 1978) had showed a linear time course with absence of saturation at substrate concentrations of 0.001 to $1 \mathrm{mM}$. Dicarboxylic amino acid uptake by FA and DCA fibroblasts was also found to be linear with time. An incubation time of $15 \mathrm{~min}$ was chosen for further experiments.

Oxidation of glutamic acid (table II)

The rate of Glu oxidation was lower in FA and DCA fibroblasts but without statistically significant differences. Less than $1 \%$ of the radioactivity incorporated into the cells was accounted for into the ${ }^{14} \mathrm{CO}_{2}$ trapped.

\section{Kinetic Analysis (table III and IV)}

The rate of dicarboxylic amino acid uptake by fibroblasts increased with increasing concentration of dicarboxylic amino acids in the incubation medium. At concentrations above 0.5 $\mathrm{mM}$, the rate of both Asp and Glu decreased without saturation. Analysis of the data obtained for Asp uptake disclosed a significant decrease in velocity at substrate concentrations below $0.5 \mathrm{mM}$ for DCA fibroblasts alone. At high substrate concentrations (above $0.5 \mathrm{mM}$ ) the $\mathrm{Km}$ and Vmax of FA and DCA fibroblasts were higher, but without statistically significant difference from control cells. The apparent $\mathrm{Km}$ for Glu uptake was comparable if not identical to the $\mathrm{Km}$ for Asp at low substrate concentrations. However, the uptake velocity was $2.5 \times$ greater for Glu than Asp. At high substrate concentration, both $\mathrm{Km}$ and Vmax values for Glu were higher than Asp. Although FA and DCA fibroblasts showed lower than control uptake kinetics for Glu at high concentrations, the difference observed was not significant.

\section{Metabolic Inhibition (table V)}

Potassium cyanide (KCN) and iodoacetate were the only two amongst respiration blockers and oxidative phosphorylation uncouplers which diminished Glu and Asp uptake in fibroblasts. The reduction of Glu uptake was definitely marked in DCA fibroblasts. The sulfhydryl reagents, N-ethyl-maleimide (NEM), cupric ions $\left(\mathrm{CuSO}_{4}\right)$ and $\mathrm{N}, \mathrm{N}$-dimethyl amide (Diamide) were in decreasing order, effective inhibitors of Glu and Asp uptake. Chloramphenicol, an antibiotic which inhibits protein synthesis by interfering with peptide-forming steps, reduced Glu and Asp acid uptake but to a lesser degree than phosphorylation uncouplers. Chlorpromazine (CPZ) and Ouabain were the most potent of all inhibitors for the low $\mathrm{Km}$ Glu uptake system, suggesting that $95 \%$ of Glu uptake was dependent on

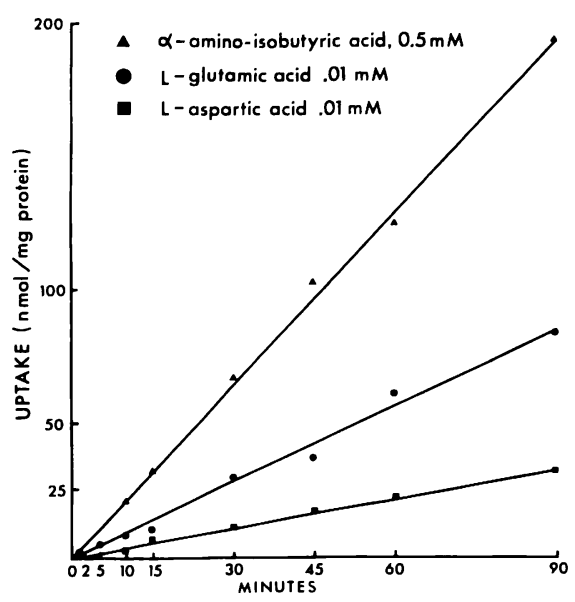

Figure 1 -Time course of dicarboxylic amino acids and Aib uptake in cultured skin fibroblasts

TABLE II

Oxidation of Glutamic Acid by Intact Cultured Skin Fibroblasts from Controls and Patients with Friedreich's Ataxia and Dicarhoxylic Aminoaciduria

\begin{tabular}{cc}
\hline Cell lines & Glutamic Acid Oxidized * \\
\hline (number) & $(\mathrm{pmol} / \mathrm{min} / \mathrm{mg}$ protein $)$ \\
mean $\pm \mathrm{SD}$ \\
$\begin{array}{c}\text { controls } \\
(5)\end{array}$ & $3.0 \pm 1.3$ \\
$\begin{array}{c}\text { Friedreich's } \\
(4) \\
\text { dicarboxylic } \\
(2)\end{array}$ & $2.1 \pm 1.2$ \\
\hline
\end{tabular}

* Calculated from ${ }^{14} \mathrm{C}_{2}$ trapped in $0.1 \mathrm{~N} \mathrm{KOH}$, after incubation of fibroblasts $(50 \mu \mathrm{g}$ protein equivalent) with L-glutamic acid $0.025 \mathrm{mM}\left(0.25 \mu \mathrm{Ci}\right.$ of L-U-14-C-glutamic acid) for $15 \mathrm{~min}$. at $37^{\circ}$ in $1 \mathrm{ml}$ of phosphate buffered saline. 
TABLE III

Km (mM) and Vmax (nmol/min/mg protein) of Aspartic Acid Uptake by Cultured Skin Fibroblasts from Normal Controls and Patients with Friedreich Ataxia and Dicarboxylic Aminoaciduria

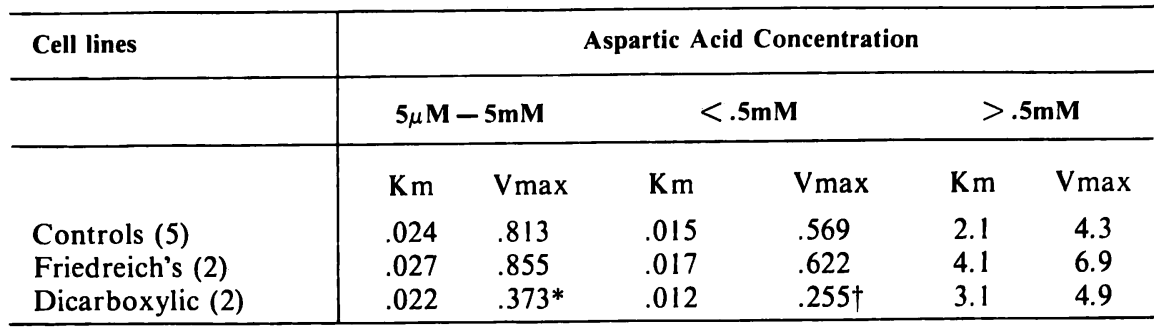

${ }^{*} \mathrm{p}<.05$ for differences from controls

$t p<.02$ for differences from controls and $<.05$ from Friedreich's

the activity of $\mathrm{Na}+\mathrm{K}+-\mathrm{ATPase}$. The inhibitory effect of membrane active compounds such as lidocaine, quinidine and $\mathrm{D}$, L-propanolol was not different in diseased and control lines. Isoproterenol, dibutyryl cyclic AMP, and theophylline enhanced Glu uptake in all cell lines. Insulin, alloxan monohydrate, and 3-acetyl pyridine, which cause significant changes in the intracellular concentration of dicarboxylic amino acids in other mammalian transport systems, did not permit differentiation between FA cells and control fibroblasts. Finally, m-chlorocarbonylcyanide phenylhydrazone (CCCP), an uncoupler which permits the rapid exchange of $\mathrm{H}^{+}$ across membranes and thus discharges both $\mathrm{pH}$ and electrical gradients, was a good inhibitor of Glu uptake only when preincubated with the fibroblasts before uptake experiments.

Buffer composition and temperature (table VI, fig 2 and 3)

Potassium, calcium, and sodium ions were, in increasing order, the most required cations for efficient dicarboxylic amino acids uptake, Magnesium appeared slightly inhibitory when glucose containing PBSG was used in Glu uptake experiments. Similarly, calcium dependent uptake of both Glu and Asp was more evident in glucose free PBS. Sodium dependent dicarboxylic amino acid uptake was progressively restored by increasing concentrations of sodium, from 10 to $100 \mathrm{mM}$. However, fibroblasts incubated in $100 \mathrm{mM} \mathrm{K}$ and $50 \mathrm{mM} \mathrm{Na}{ }^{+}$showed a significant decrease in dicarboxylic amino acid uptake corresponding to a level observed with $10 \mathrm{mM}$ sodium alone. Phosphate ions had an inhibitory effect in the presence of glucose and the opposite effect in the absence of glucose. Both Glu and Asp uptake decreased at $4^{\circ} \mathrm{C}$, down to approximately $10 \%$ of the initial $37^{\circ} \mathrm{C}$ uptake levels. Significant differences between FA and control fibroblasts were found with respect to calcium dependent Asp uptake in glucose free PBS only. DCA fibroblasts were likewise less magnesium and calcium dependent for Glu uptake in glucose containing PBSG. The same DCA fibroblasts differed from control fibroblasts in their lesser dependance on sodium (in $\mathrm{Na}^{+}$free, and $\mathrm{Na}^{+} 50, \mathrm{~K}^{+} 100 \mathrm{mM}$ ) and temperature (at $22^{\circ}$ only) for Glu uptake in PBSG. Glucose related uptake of Glu was significantly decreased in $\mathrm{P}^{4}$ depleted FA and DCA fibroblasts, in magnesium depleted FA fibroblasts, and finally in all three calcium depleted cell lines.

\section{TABLE IV}

$\mathrm{Km}(\mathrm{mM})$ and Vmax (nmol/min/mg protein) of glutamic acid uptake hy cultured skin fibroblasts from normal controls and patients with Friedreich Ataxia and dicarboxylic aminoaciduria

\begin{tabular}{l|cccc}
\hline Cell lines & \multicolumn{4}{|c}{ Glutamic Acid Concentration } \\
\hline & \multicolumn{2}{|c}{$5 \mu \mathbf{M}-1 \mathbf{m M}$} & \multicolumn{2}{c}{$1-20 \mathrm{mM}$} \\
\hline & $\mathrm{Km}$ & $\mathrm{V} \max$ & $\mathrm{Km}$ & $\mathrm{Vmax}$ \\
Controls & .025 & $2.0(13)^{*}$ & 24.7 & $148.3(6)$ \\
Friedreich's & .031 & $2.3(5)$ & 11.3 & $64.6(2)$ \\
Dicarboxylic & .035 & $1.6(5)$ & 15.3 & $103.3(2)$ \\
\hline
\end{tabular}

* Number of cell lines studied
Inhibition by other amino acids (table VII)

Previous experiments suggested that the uptake of $0.01 \mathrm{mM}$ dicarboxylic amino acids was not inhibited significantly by $1 \mathrm{mM}$ glycine, $\alpha$-alanine, leucine, or taurine (fig 4 and 5). The present data (table VII) revealed that Glu uptake is markedly inhibited by $L$ and Daspartic acid, L-glutamic acid, and Lglutamine. Glu uptake was also inhibited to varying degrees in order of decreasing inhibition by: serine, threonine, isoleucine, asparagine, methionine, cysteine, valine, and the aromatic amino acids tyrosine and phenylalanine. D-glutamic acid was not inhibitory at a concentration of $1 \mathrm{mM}$, and further experiments revealed that the D-isomer of aspartic acid was a significantly more potent inhibitor of both L-glu and L-asp uptake (table VIII and fig. 6 and 7), for the same inhibitor concentrations. We found no significant difference in the degree or stereospecificity of inhibition by other amino acids between control and patients fibroblasts.

\section{Effect of time in culture (fig 8)}

Aging slowly but clearly reduced the uptake of Asp by control fibroblasts. This reduction was less apparent in FA fibroblasts and not at all present in DCA fibroblasts where low Asp uptake values were observed at the early passages. Glu uptake increased with time up to the 12th passage, and decreased thereafter, showing very good parallelism between all three groups of fibroblasts studied. The overall uptake values of Asp were 


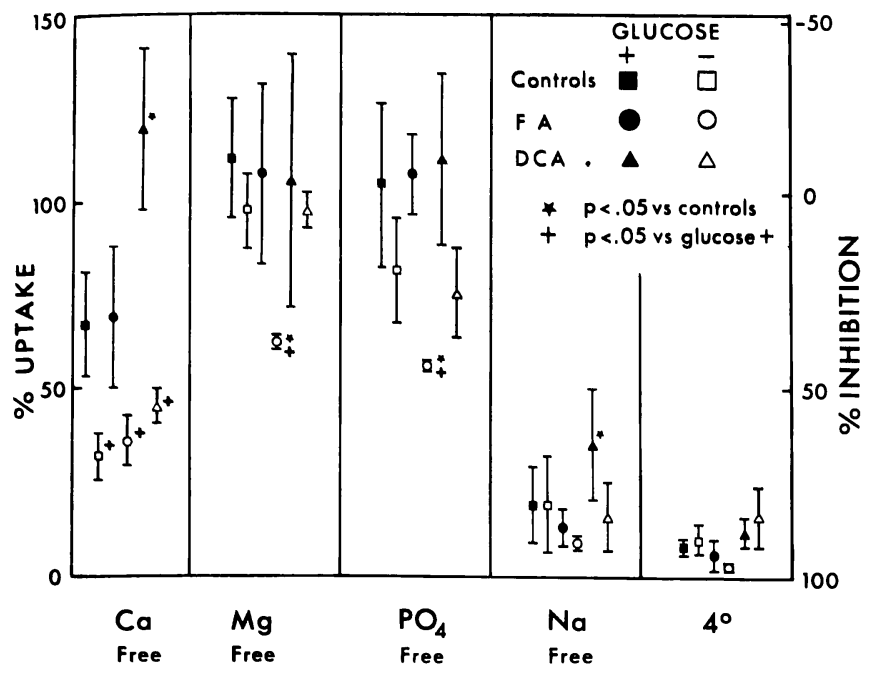

Figure 2-Influence of glucose depletion on dicarboxylic (Glu) amino acids uptake by cultured human skin fibroblasts

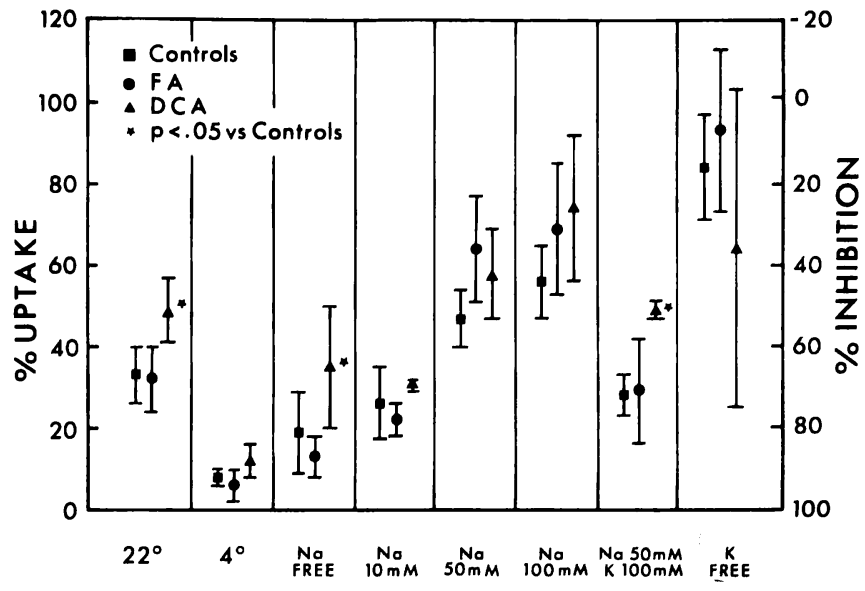

Figure 3-Influence of sodium and potassium on dicarboxylic (Glu) amino acid uptake by cultured skin fibroblasts

TABLE V

Effect of Metabolic Inhibitors on Dicarboxylic Amino Acids Uptake by Cultured Human Skin Fibroblasts

\begin{tabular}{|c|c|c|c|c|c|c|c|}
\hline & & \multicolumn{3}{|c|}{ Glutamic Acid } & \multicolumn{3}{|c|}{ Aspartic Acid } \\
\hline & & $\begin{array}{c}\text { controls } \\
(n: 6)\end{array}$ & $\begin{array}{l}\text { F.A. } \\
(n: 2)\end{array}$ & $\begin{array}{c}\text { D.C.A. } \\
(n: 2)\end{array}$ & $\begin{array}{c}\text { controls } \\
(n: 6)\end{array}$ & $\begin{array}{l}\text { F.A. } \\
(n: 2)\end{array}$ & $\begin{array}{c}\text { D.C.A. } \\
(\mathrm{n}: 2)\end{array}$ \\
\hline None & & $100 \%$ & $100 \%$ & $100 \%$ & $100 \%$ & $100 \%$ & $100 \%$ \\
\hline $\mathrm{NaF}$ & $.025 \mathrm{mM}$ & $105 \pm 13$ & $110 \pm 8$ & $103 \pm 10$ & $105 \pm 15$ & $103 \pm 21$ & $94 \pm 6$ \\
\hline $\mathrm{NaNO}_{3}$ & $.025 \mathrm{mM}$ & $95 \pm 15$ & $95 \pm 28$ & $106 \pm 18$ & $102 \pm 9$ & $92 \pm 13$ & $96 \pm 6$ \\
\hline $\mathrm{KCN}$ & $.025 \mathrm{mM}$ & $75 \pm 16$ & $82 \pm 1$ & $* 44 \pm 33$ & $109 \pm 19$ & $106 \pm 40$ & $117 \pm 5$ \\
\hline lodoacetate & $.025 \mathrm{mM}$ & $55 \pm 7$ & $64 \pm 3$ & $85 \pm 34$ & $63 \pm 7$ & $68 \pm 16$ & $51 \pm 23$ \\
\hline NEM & $.025 \mathrm{mM}$ & $73 \pm 12$ & $59 \pm 9$ & $66 \pm 4$ & $65 \pm 10$ & $73 \pm 8$ & - \\
\hline $\mathrm{CuSO}_{4} \uparrow$ & $.025 \mathrm{mM}$ & $87 \pm 11$ & $97 \pm 25$ & $98 \pm 25$ & - & - & - \\
\hline Diamide & $.025 \mathrm{mM}$ & $97 \pm 13$ & $98 \pm 10$ & $84 \pm 1$ & $107 \pm 14$ & $81 \pm 39$ & $94 \pm 28$ \\
\hline Chloramphenicol & $.025 \mathrm{mM}$ & $85 \pm 13$ & $84 \pm 5$ & $107 \pm 13$ & $89 \pm 24$ & $107 \pm 36$ & $73 \pm 5$ \\
\hline $\mathrm{CPZ} \dagger$ & $.2 \mathrm{mM}$ & $5 \pm 1$ & $7 \pm 1$ & $7 \pm 5$ & - & - & - \\
\hline Ouabain & $.025 \mathrm{mM}$ & $47 \pm 7$ & $70 \pm 2$ & $44 \pm 11$ & $44 \pm 9$ & $61 \pm 1$ & $* 28 \pm 4$ \\
\hline Lidocaine $†$ & $.025 \mathrm{mM}$ & $144 \pm 13$ & $141 \pm 17$ & $171 \pm 61$ & - & - & - \\
\hline Quinidine & $.1 \mathrm{mM}$ & $44 \pm 4$ & $44 \pm 4$ & $38 \pm 4$ & $87 \pm 7$ & $85 \pm 23$ & $86 \pm 10$ \\
\hline Propanolol & $.2 \mathrm{mM}$ & $62 \pm 14$ & $62 \pm 9$ & $75 \pm 6$ & $49 \pm 9$ & $52 \pm 23$ & $* 68 \pm 1$ \\
\hline Isoproterenol $\dagger$ & $.2 \mathrm{mM}$ & $116 \pm 20$ & $119 \pm 25$ & $141 \pm 11$ & - & - & - \\
\hline DBcAMP† & $.025 \mathrm{mM}$ & $129 \pm 19$ & $144 \pm 50$ & $144 \pm 5$ & - & - & - \\
\hline Theophylline & $.025 \mathrm{mM}$ & $140 \pm 31$ & $118 \pm 12$ & $166 \pm 59$ & & & \\
\hline Insulin $\dagger$ & $100 \mu \mathrm{u} / \mathrm{ml}$ & $135 \pm 24$ & $147 \pm 54$ & $163 \pm 25$ & - & - & - \\
\hline Alloxane & $.01 \mathrm{mM}$ & $86 \pm 7$ & $96 \pm 17$ & $99 \pm 18$ & $80 \pm 8$ & $77 \pm 22$ & $93 \pm 16$ \\
\hline 3-APyr $†$ & $.01 \mathrm{mM}$ & $87 \pm 8$ & $92 \pm 29$ & $119 \pm 14$ & - & - & - \\
\hline $\mathrm{CCCP}$ & $.01 \mathrm{mM}$ & $50 \pm 7$ & $67 \pm 1$ & $40 \pm 15$ & $67 \pm 6$ & $74 \pm 8$ & $* 48 \pm 3$ \\
\hline $\mathrm{CCCP}+$ & $.01 \mathrm{mM}$ & $84 \pm 15$ & $95 \pm 32$ & $99 \pm 16$ & - & - & - \\
\hline
\end{tabular}




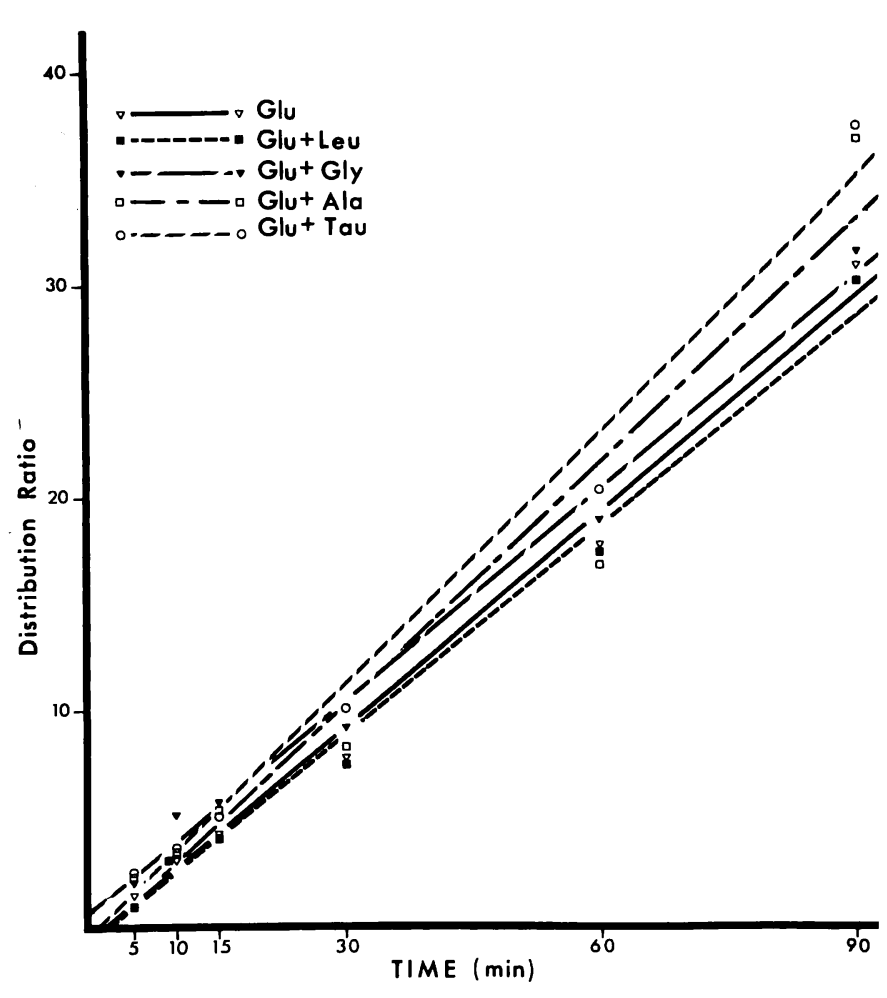

Figure 4-Effect of other acids ( $1 \mathrm{mM})$ on glutamic acid $(10 \mu \mathrm{M})$ uptake by cultured skin fibroblasts

significantly reduced in DCA fibroblasts $(\mathrm{p}<.01)$ as compared with control and FA fibroblasts (table IX). Although Glu uptake was reduced in FA and more specifically in DCA fibroblasts, the difference was not statistically significant.

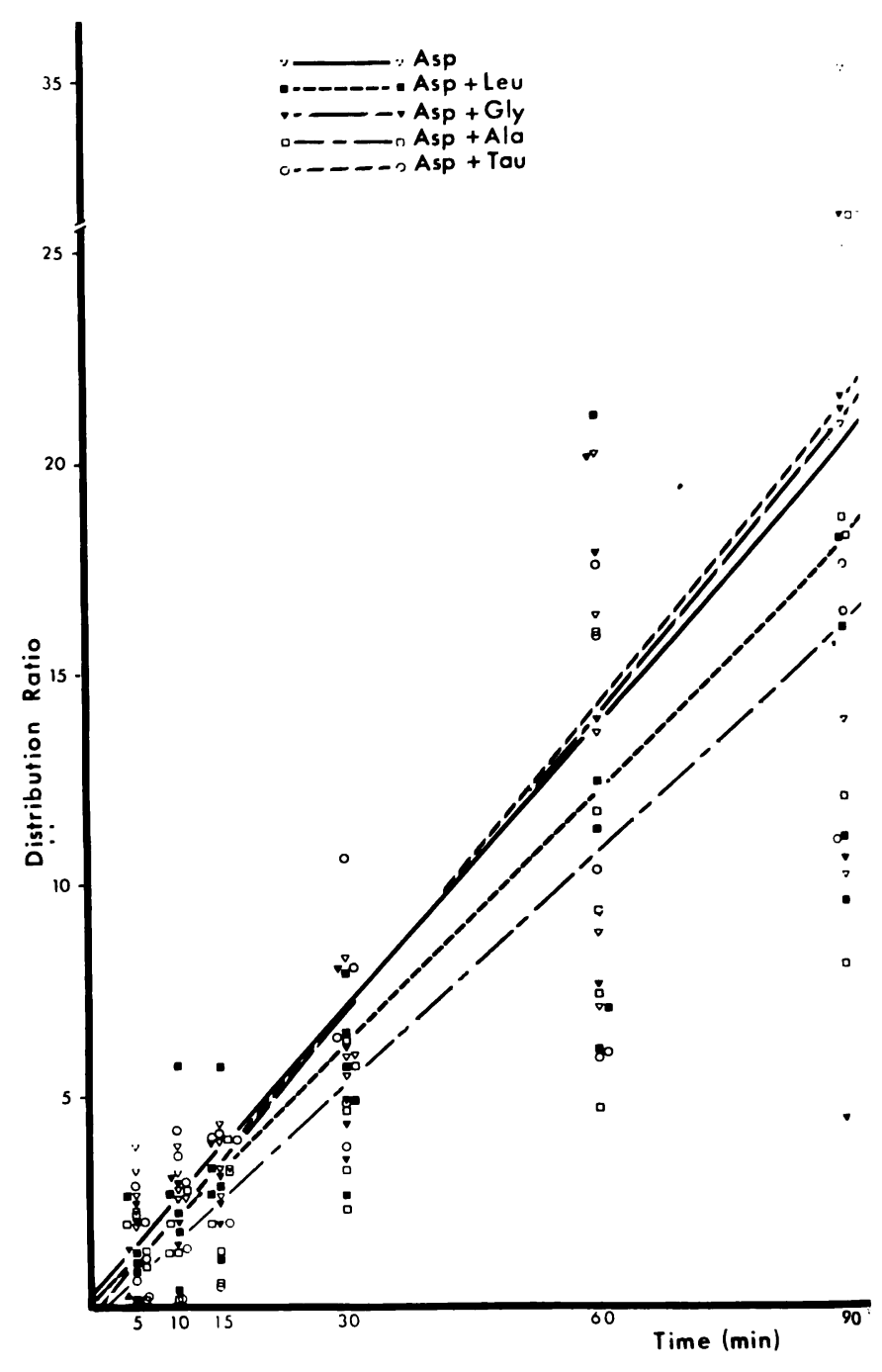

Figure 5-Effect of other amino acids $(1 \mathrm{mM})$ on aspartic acid $(10 \mu \mathrm{M})$ uptake by cultured skin fibroblasts

\section{DISCUSSION}

The present studies sought to define the uptake processes for glutamic and aspartic acid in cultured fibroblasts from normal individuals and patients with Friedreich's Ataxia, using dicarboxylic aminoaciduria fibroblasts as diseased controls. Results of the oxidation studies revealed that FA fibroblasts do not rely more than control or DCA fibroblasts on external glutamate for operation of the tricarboxylic acid cycle. A very small proportion $(1 \%)$ of the glutamic acid taken up by the cells was oxidized, suggesting that the greater part of transported Glu remained free or incorporated into cell proteins (Novogrodsky et al., 1977). Although the kinetics of dicarboxylic amino acid uptake must be interpreted cautiously, a number of characteristic observations were valid.

The apparent $\mathrm{Km}$ values obtained for all three cell lines were similar, but the Vmax values for the DCA fibroblasts were lower with respect to aspartic acid uptake at low substrate concentration $(.025 \mathrm{mM})$. These data suggest a comparable affinity of the dicarboxylic amino acid carrier for Asp and Glu in all cell lines, but a depressed movement or a reduced rate of dissociation of dicarboxylic amino acid from the carrier in DCA fibroblasts at low substrate concentrations.
Since this low $\mathrm{Km}$ system would be the major one operative in vivo at physiological concentrations of Asp and Glu in biological fluids (Lemieux et al., 1976), the apparent high $\mathrm{Km}$ uptake system of dicarboxylic amino acids was not further investigated.

The effect of metabolic inhibitors revealed that uncouplers of oxidative phosphorylation were inhibitory to Glu and Asp uptake. Sulfhydryl reagents also showed some inhibition, suggesting the relative importance of free sulfhydryl groups in transferring dicarboxylic amino acids across the fibroblast membrane. Chlorpromazine inhibited Glu uptake down to levels seen only with sodium 


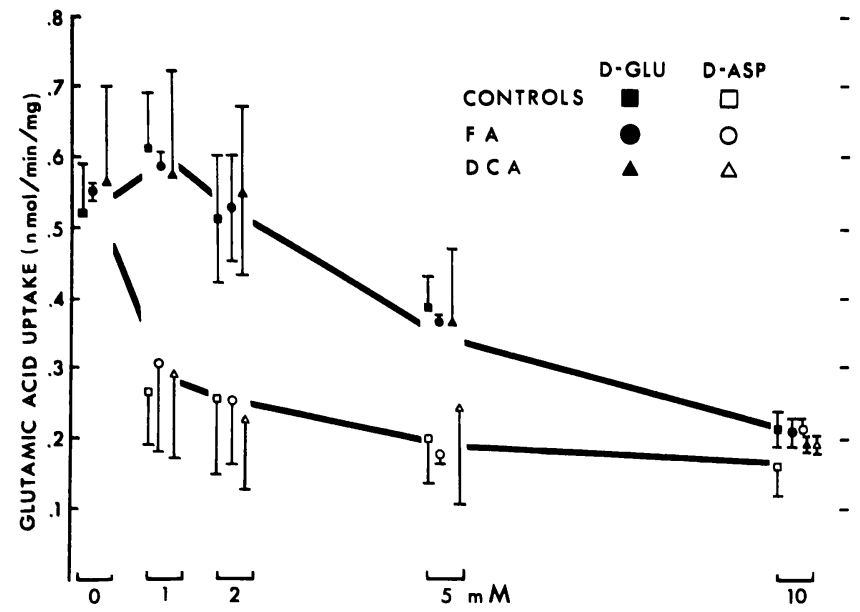

Figure 6-Inhibitory effect of D-gluta mic and D-aspartic acids on L-glutamic uptake by cultured skin fibroblasts

deprivation and very low ambient temperature. Chlorpromazine is known to inhibit $\mathrm{Na}^{+}, \mathrm{K}^{+}$-ATPase activity of brain microsomes, human leukocytes, and isolated rat liver slices (Akeda and Brody, 1969).

It is assumed that the chlorpromazine free radical interacts with the enzyme's free sulfhydryl groups thus creating an irreversible inhibition (Samuel and Carey, 1978). Further, it has been suggested that chlorpromazine can localize at cell membranes phospholipid protein interfaces, causing an expansion of the cell membrane (Seeman et al., 1969). Our results were in agreement with both modes of chlorpromazine action since ouabain or sodium depletion (table VI), which mimics $\mathrm{Na}^{+}, \mathrm{K}^{+}$ATPase inhibition, could only abolish Glu uptake by approximately $80 \%$ with comparison to $95 \%$ inhibition by chlorpromazine alone.

Propanolol, lidocaine, and quinidine which inhibit the incorporation of leucine into protein as a consequence of a reduction in uptake at the cell membrane (Schoenfeld et al., 1977) also disorganize lipid molecules and induce changes in the proteins located in the outer layers of the membranes (Poste et al., 1975). These membrane active compounds were less effective against dicarboxylic amino acid than against $\beta$-aminoisobutyric acid uptake as previously reported for chick embryo liver cells in culture (Schoenfeld et al., 1977), particularly skin fibroblasts

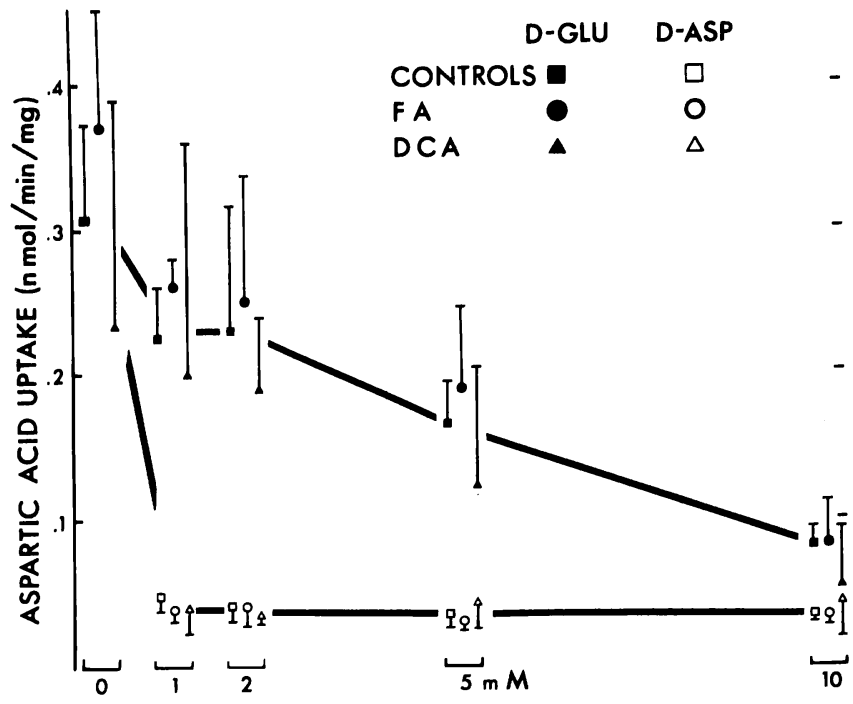

Figure 7-Inhibitory effect of D-glutamic and D-aspartic acids on L-aspartic acid uptake by cultured skin fibroblasts

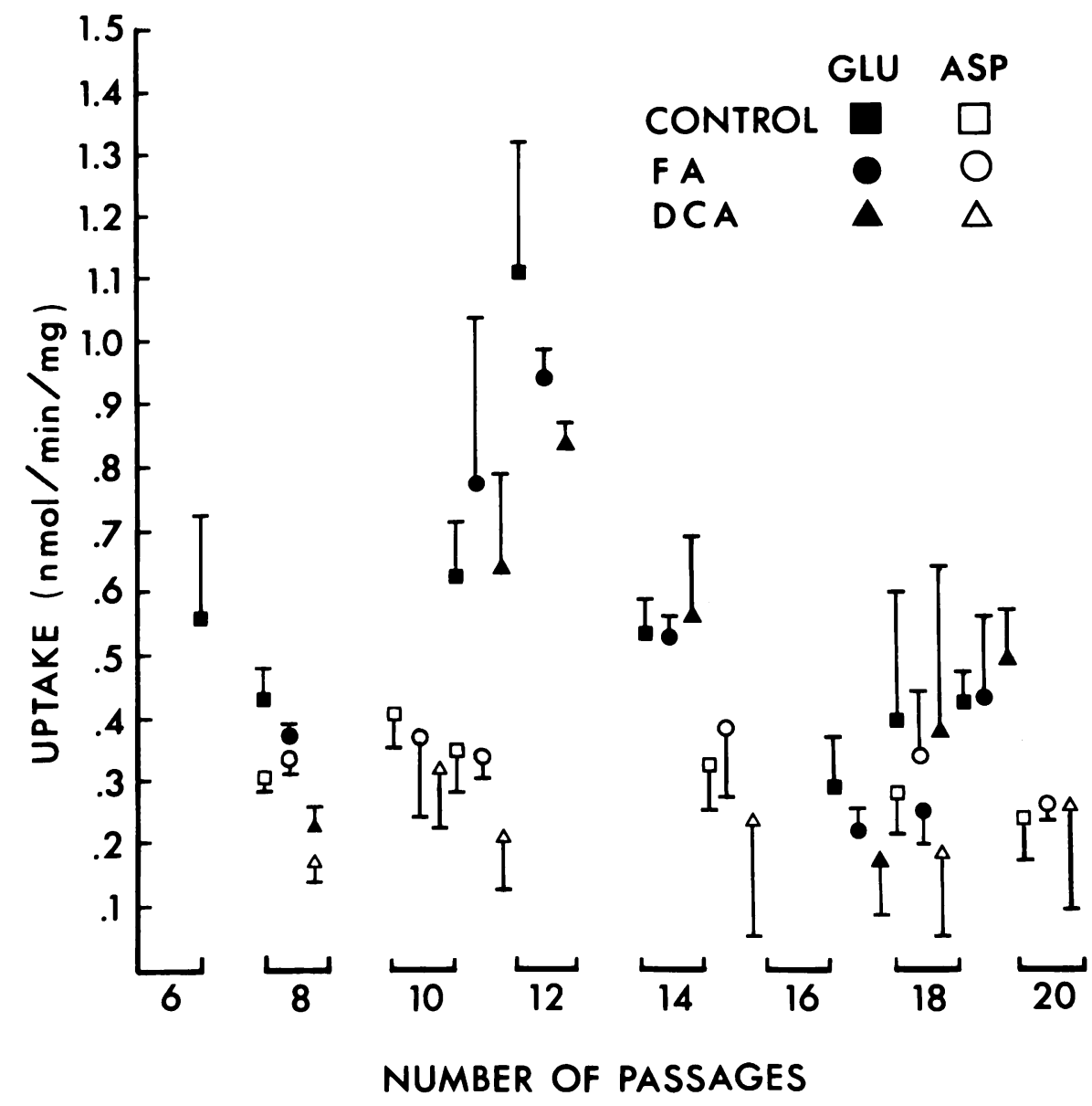

Figure 8-Influence of time in culture on dicarboxylic amino acids uptake by 
TABLE VI

Influence of Buffer Composition and Temperature on Dicarboxylic Amino Acid Uptake in Control, Friedreich's Ataxia and Dicarboxylic Aminoaciduria Cultured Skin Fibrohlasts

\begin{tabular}{|c|c|c|c|c|c|c|c|}
\hline \multirow[t]{2}{*}{ Buffer } & \multirow[t]{2}{*}{ Ion Deleted } & \multicolumn{3}{|c|}{ \% Glutamic Uptake } & \multicolumn{3}{|c|}{ \% Aspartic Uptake } \\
\hline & & Control & FA & DCA & Control & $\mathbf{F A}$ & DCA \\
\hline $\begin{array}{l}\text { PBS } \pm G \\
\text { PBSG } \\
\text { PBS }\end{array}$ & $\begin{array}{l}\text { None } \\
\mathrm{Ca} \text { free } \\
\mathrm{Ca} \text { free }\end{array}$ & $\begin{array}{c}100 \pm S D(n) \\
67 \pm 14(12) \\
32 \pm 6(6) \S g\end{array}$ & $\begin{array}{l}100 \pm S D(n) \\
69 \pm 19(4) \\
36 \pm 7(2) \pm g\end{array}$ & $\begin{array}{l}100 \pm S D(n) \\
119 \pm 22(4) \S c \\
45 \pm 5(2) \dagger g\end{array}$ & $\begin{array}{c}100 \pm \mathrm{SD}(\mathrm{n}) \\
35 \pm 14(12) \\
29 \pm 2(5)\end{array}$ & $\begin{array}{l}100 \pm \mathrm{SD}(\mathrm{n}) \\
39 \pm 14(4) \\
51 \pm 4(2) \S c\end{array}$ & $\begin{array}{c}100 \pm \mathrm{SD}(\mathrm{n}) \\
38 \pm 10(4) \\
32 \pm 2(2)\end{array}$ \\
\hline $\begin{array}{l}\text { PBSG } \\
\text { PBS }\end{array}$ & $\begin{array}{l}\mathrm{Mg} \text { free } \\
\mathrm{Mg} \text { free }\end{array}$ & $\begin{array}{c}111 \pm 16(12) \\
97 \pm 10(6)\end{array}$ & $\begin{array}{l}107 \pm 24(3) \\
62 \pm 1(2) \pm c g\end{array}$ & $\begin{array}{r}105 \pm 34(3) \\
97 \pm 5(2)\end{array}$ & $\begin{array}{l}89 \pm 18(2) \\
93 \pm 14(6)\end{array}$ & $\begin{array}{l}88 \pm 7(4) \\
94 \pm 18(2)\end{array}$ & $\begin{array}{r}100 \pm 20(4) \\
99 \pm 1(2)\end{array}$ \\
\hline PBSG & $K$ free & $84 \pm 13(6)$ & $93 \pm 20(2)$ & $64 \pm 39(2)$ & $57 \pm 15(6)$ & $96 \pm 30(2)$ & $80 \pm 1(2)$ \\
\hline $\begin{array}{l}\text { PBSG } \\
\text { PBS }\end{array}$ & $\begin{array}{l}\mathrm{Na} \text { free } \\
\mathrm{Na} \text { free }\end{array}$ & $\begin{array}{l}19 \pm 10(12) \\
19 \pm 13(6)\end{array}$ & $\begin{array}{r}13 \pm 5(4) \\
9 \pm 2(2)\end{array}$ & $\begin{array}{l}35 \pm 15(4) \dagger c \\
16 \pm 9(2)\end{array}$ & $\begin{array}{l}8 \pm 7(12) \\
7 \pm 1(6)\end{array}$ & $\begin{array}{l}8 \pm 5(4) \\
14 \pm 6(2)\end{array}$ & $\begin{array}{l}10 \pm 6(4) \\
10 \pm 1(2)\end{array}$ \\
\hline $\begin{array}{l}\text { PBSG } \\
\text { PBSG } \\
\text { PBSG } \\
\text { PBSG }\end{array}$ & $\begin{array}{l}\mathrm{Na} 10 \mathrm{mM} \\
\mathrm{Na} 50 \mathrm{mM} \\
\mathrm{Na} 100 \mathrm{mM} \\
\mathrm{Na} 50, \mathrm{~K} 100 \mathrm{mM}\end{array}$ & $\begin{array}{l}26 \pm 9(6) \\
47 \pm 7(6) \\
56 \pm 9(6) \\
28 \pm 5(6)\end{array}$ & $\begin{array}{l}22 \pm 44(2) \\
64 \pm 13(2) \\
69 \pm 16(2) \\
29 \pm 13(2)\end{array}$ & $\begin{array}{c}31 \pm 1(2) \\
58 \pm 11(2) \\
74 \pm 18(2) \\
49 \pm 2(2)+c\end{array}$ & $\begin{array}{l}17 \pm 10(6) \\
33 \pm 21(6) \\
51 \pm 32(6) \\
22 \pm 12(6)\end{array}$ & $\begin{array}{l}39 \pm 37(2) \\
35 \pm 22(2) \\
33 \pm 28(2) \\
25 \pm 14(2)\end{array}$ & $\begin{array}{l}24 \pm 5(2) \\
27 \pm 1(2) \\
69 \pm 4(2) \\
25 \pm 8(2)\end{array}$ \\
\hline $\begin{array}{l}\text { Tris-G } \\
\text { Tris }\end{array}$ & $\begin{array}{l}\text { P04 free } \\
\text { P04 free }\end{array}$ & $\begin{array}{c}104 \pm 22(12) \\
81 \pm 14(6)\end{array}$ & $\begin{array}{l}107 \pm 11(4) \\
56 \pm 1(2) \dagger \mathrm{cg}\end{array}$ & $\begin{array}{l}111 \pm 23(4) \\
75 \pm 12(2) \S g\end{array}$ & $\begin{array}{c}112 \pm 37(12) \\
82 \pm 13(6)\end{array}$ & $\begin{array}{l}105 \pm 32(4) \\
80 \pm 4\end{array}$ & $\begin{array}{r}124 \pm 48(4) \\
90 \pm 4(2)\end{array}$ \\
\hline $\begin{array}{l}\text { PBSG } \\
\text { PBSG } \\
\text { PBS } \\
\end{array}$ & $\begin{array}{l}\text { None } 22^{\circ} \\
\text { None } 4^{\circ} \\
\text { None } 4^{\circ} \\
\end{array}$ & $\begin{array}{l}33 \pm 7(6) \\
8 \pm 2(12) \\
10 \pm 4(6) \\
\end{array}$ & $\begin{array}{r}32 \pm 8(2) \\
6 \pm 4(3) \\
4 \pm 1(2) \\
\end{array}$ & $\begin{array}{l}49 \pm 8(2) \dagger c \\
12 \pm 4(3) \\
16 \pm 8(2) \\
\end{array}$ & $\begin{array}{c}25 \pm 4(6) \\
9 \pm 6(11) \\
3 \pm 2(6) \\
\end{array}$ & $\begin{array}{l}19 \pm 4(2) \\
12 \pm 6(4) \\
14 \pm 1(2)\end{array}$ & $\begin{array}{l}22 \pm 3(2) \\
14 \pm 5(4) \\
14 \pm 10(2)\end{array}$ \\
\hline
\end{tabular}

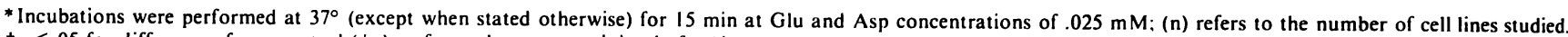
$\dagger p<.05$ for differences from control $(+\mathrm{c})$ or from glucose containing bufer $(\dagger \mathrm{g})$

$\ddagger p<.01$ for differences from control $(\ddagger c)$ or from glucose containing buffer $(+g)$

$\S \mathrm{p}<.001$ for differences from control $(\$ \mathrm{c})$ or from glucose containing buffer $(\$ \mathrm{~g})$

TABLE VII

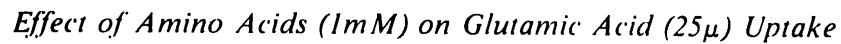
by Cultured Human Skin Fibroblasts

\begin{tabular}{|c|c|c|c|c|c|c|}
\hline \multirow[t]{2}{*}{ Amino Acids } & \multicolumn{6}{|c|}{$\begin{array}{c}\% \begin{array}{c}\text { Glutamic Acid Uptake } \\
(\text { mean } \pm \text { SD) }\end{array} \\
\end{array}$} \\
\hline & \multicolumn{2}{|c|}{ controls (4) } & \multicolumn{2}{|c|}{ FA (2) } & \multicolumn{2}{|c|}{ DCA (2) } \\
\hline None $100 \%$ & \multicolumn{2}{|c|}{$100 \%$} & \multicolumn{2}{|c|}{$100 \%$} & \multicolumn{2}{|c|}{$100 \%$} \\
\hline Ornithine* & $124=$ & 34 & 99 & 4 & 114 & 20 \\
\hline$\beta$-alanine & 103 & 17 & 129 & 18 & 115 & 4 \\
\hline Lysine & 104 & 31 & 92 & 1 & 100 & 9 \\
\hline Histidine & 115 & 43 & 91 & 34 & 80 & 4 \\
\hline D-glutamic & 97 & 16 & 85 & 20 & 108 & 15 \\
\hline Proline & 95 & 30 & 78 & 10 & 83 & 6 \\
\hline Arginine & 85 & 12 & 76 & 15 & 104 & 16 \\
\hline Phenylalanine & 83 & 3 & 97 & 38 & 92 & 1 \\
\hline Tyrosine & 78 & 26 & 61 & 5 & 76 & 20 \\
\hline Valine & 73 & 26 & 71 & 14 & 72 & 6 \\
\hline Cysteine & 60 & 10 & 54 & 10 & 97 & 40 \\
\hline Methionine & 69 & 17 & 67 & 10 & 69 & 4 \\
\hline Asparagine & 67 & 17 & 69 & 11 & 63 & 4 \\
\hline Isoleucine & 68 & 15 & 66 & 1 & 60 & 1 \\
\hline Thréonine & 69 & 23 & 60 & 8 & 59 & 6 \\
\hline Serine & 58 & 6 & 59 & 12 & 64 & 3 \\
\hline Glutamine & 44 & 4 & 44 & 10 & 44 & 4 \\
\hline Glutamic & 23 & 7 & 21 & 4 & 19 & 1 \\
\hline Aspartic & 23 & 5 & 40 & 2 & 54 & 17 \\
\hline D-aspartic & 22 & 5 & 36 & 7 & 58 & 18 \\
\hline
\end{tabular}

* Except for D-aspartic and D-glutamic, all amino acids were L-isomers lidocaine, which in liver cells inhibited $\alpha$-AIB uptake by 22 to $38 \%$ as compared to a 41 to $71 \%$ stimulation in cultured skin fibroblasts.

Propanolol-mediated inhibition of dicarboxylic amino acid uptake may also be through its $\beta$-adrenergic antagonism as reported for $\beta$-amino acid transport in mammalian kidney slices (Chesney et al., 1978). Isoproterenol, a $\beta$-adrenergic agonism enhanced Glu uptake by $16-41 \%$ over basal conditions. A possible mechanism might be through activation of adenylate cyclase, with subsequent formation of cyclic AMP.

Involvement of cyclic AMP was further supported by a $29-44 \%$ increase in Glu uptake by fibroblasts incubated with dibutyryl cyclic AMP, and a $18-66 \%$ increase during incubation with the phosphodiesterase inhibitor theophylline. Cyclic AMP has been reported to stimulate amino acid uptake into a variety of tissues, including bone (Phang et al., 1970), kidney (Weiss et al, 1972), uterus (Griffin and Szego, 1968), liver (Tews et al., 1970), heart (Huxtable and 
TABLE VIII

Effect of D-Glutamic and D-Aspartic Acids on Dicarhoxilic Amino Acids Uptake in Cultured Human Skin Fibroblasts

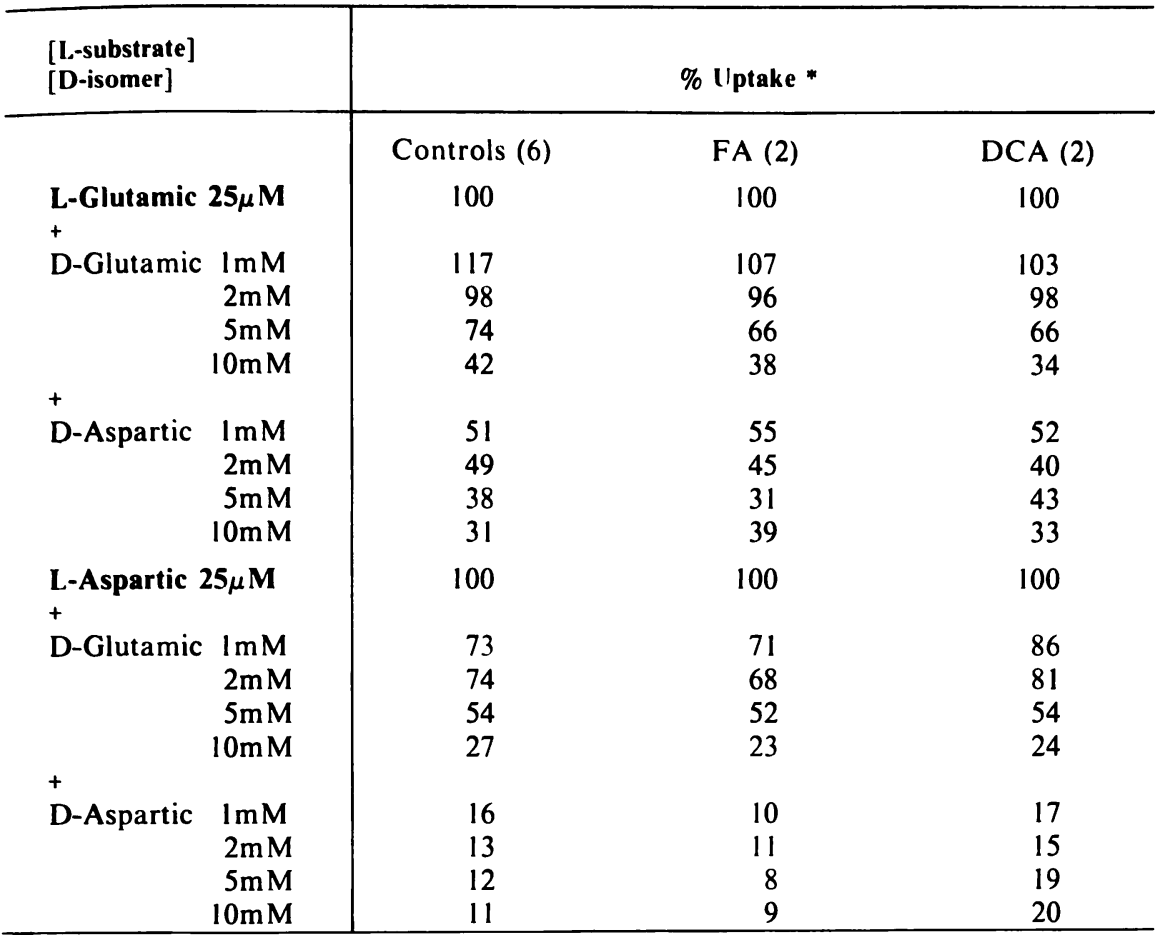

* mean percentage of uptake as compared to uninhabited fibroblasts
Chubb, 1977), and intestine (Kinzie et al., 1976). The changes in uptake were apparently due to an altered electrochemical gradient across the cell with an increased external sodium concentration. High sodium concentrations in the incubation medium were also responsible for stimulation of dicarboxylic amino acids. FA and DCA fibroblasts appeared slightly more stimulated than controls in their response to DBc AMP and isoproterenol, but no statistically significant differences were found. Propanolol significantly inhibited Asp uptake in DCA fibroblasts only.

The insulin stimulated Glu uptake by cultured skin fibroblasts bears by Kilberg and Neuhaus (1977) for AIB ( $\alpha$-aminoisobutyric acid) transport in liver. These authors have shown that insulin stimulated AIB dependent amino acid transport system other than systems A (alanine preferring) or L (Leucine preferring). some similarity to system B described transport through a neutral $\mathrm{Na}^{+}$ The dicarboxylic amino acid transport system of fibroblasts was also found to be $\mathrm{Na}^{+}$dependent and insulin sensitive. Alloxane, which produces a significant decrease in the cerebellar concentration of aspartate (Butterworth et al., 1978 a) and aspartate amino transferase (Jayashree and Nayeemunnis, A., 1975), reduced minimally both Glu and Asp uptake in cultured skin fibroblasts. Intraperitoneal injection of 3-acetyl-pyridine in rats produces a cerebellar ataxia and decreased levels of glutamic acid and taurine in the cerebellum and decreased levels of aspartic acid in the retina (Butterworth et al., 1978 b). Our results of a slightly reduced uptake of Glu by skin fibroblasts incubated with 3-APyr were not suggestive of a minor interference by that chemical on dicarboxylic amino acid uptake. We recognize that many of the metabolic inhibitors should have been tested at higher concentrations, but in many cases their low level of solubility in PBSG prevented such a possibility. CCCP which completely abolishes D-lactate-energized uptake of glutamate in membrane vesicles of $\mathrm{E}$. coli, like sodium azide, a potent inhibitor of D-lactate oxidation (Macdonald et al., 1977) had very little effect on Glu uptake in fibroblasts not preincubated with the inhibitor. However, preincubation with CCCP resulted in a $50 \%$ inhibition of uptake suggesting the importance of an electochemical gradient not related to oxidation of lactate.

These results and the data from glucose and ion free incubation medium suggested that Glu and Asp uptake into skin fibroblasts involves a sodium-substrate symport. Calcium and phosphate ions were required for optimum dicarboxylic amino acid uptake in glucose-free more than in glucose-containing medium. In addition to these ions, membrane integrity as to -SH groups and protein-lipid interfaces was found of major importance for dicarboxylic amino acid uptake. Magnesium was inhibitory in glucose containing medium, but had very little effect in glucose free medium, with the exception of FA fibroblasts. The effect of inhibitor amino acids revealed that the Glu uptake system is not stereospecific and that competition
TABLE IX

Uptake of Dicarboxylic Amino Acids by Cultured Human Skin Fibroblasts (nmol/min $/ \mathrm{mg}$ protein)

\begin{tabular}{lcc}
\hline Cell lines & Aspartic & Glutamic \\
\hline & $($ mean \pm SD) & (mean \pm SD) \\
Control (6)* & $.317 \pm .06$ & $.523 \pm .26$ \\
Friedreich (2) & $.337 \pm .04$ & $.503 \pm .27$ \\
Dicarboxylic $(2)$ & $.229 \pm .06 \dagger$ & $.473 \pm .25$ \\
\hline
\end{tabular}

* number of cell lines in parenthesis

$\dagger \mathrm{p}<.01$ for difference from control and Friedreich 
occurs between $\mathrm{D}$ and L-Asp and possibly L-glutamine for the L-Glu carrier. In order to compete for the uptake sites, D-Glu concentration had to be raised to $10 \mathrm{mM}$. The competition by L-glutamine and to a lesser degree L-asparagine has to be reexamined. Either glutamine and asparagine share the dicarboxylic amino acid system as such or they are rapidly transformed into Glu and Asp during the $37^{\circ} \mathrm{C}$ incubation and act as group specific competitors (Perry et al., 1968).

Another possible explanation comes from the work of Novogrodsky et al., (1977) in human lymphoid cell lines with variable y-glutamyl transpeptidase activity. In their study, transported glutamine was extensively (80-98\%) converted to glutamate. In addition, the rate of glutamine uptake at $0.025 \mathrm{mM}$ extracellular concentration was $0.75-1.9 \mathrm{nmol} / \mathrm{min} / \mathrm{mg}$ protein as compared to our data of 0.5 $\mathrm{nmol} / \mathrm{min} / \mathrm{mg}$ protein for Glu uptake at $0.025 \mathrm{mM}$ extracellular concentration. This suggests that $1 \mathrm{mM}$ glutamine would be more rapidly taken up by the cell and transformed into glutamate, thus creating a gradient against Glu uptake.

Inhibition of Glu uptake by neutral aliphatic, branched-chain, and aromatic amino acids ranged between $40 \%$ and $0 \%$. Recent studies with cultured skin fibroblasts (Melançon et al., 1978), had shown no competition by alanine $\left(\mathrm{Na}^{+}\right.$dependent $\mathrm{A}$ system) or leucine ( $\mathrm{Na}^{+}$independent $\mathrm{L}$ system) for the dicarboxylic amino acid uptake system and no significant competition from glutamic acid for both $\mathrm{A}$ and $\mathrm{L}$ neutral amino acid transport systems (Booth and Nadler, 1975). An ASC (alanine, serine, cysteine) $\mathrm{Na}^{+}$dependent transport system has also been found operative in human cultured skin fibroblasts (Revsin and Morrow, 1976). However, this ASC system would not accept glutamic acid either since its preference would most certainly go to alanine, serine and cystine.

Taurine and $\beta$-alanine which have been shown to utilize a different uptake system in fibroblasts (see Melançon et al., this issue) were not competitors of Glu uptake in FA fibroblasts or in normal fibroblasts.
These data would suggest the following possibilities. First, dicarboxylic amino acids are mostly transported into fibroblasts through a $\mathrm{Na}^{+}$dependent, non stereospecific "uphill" transport system which requires energy from oxidative phosphorylation and is activated by cyclic AMP and insulin, and inactivated by membrane active compounds and $\mathrm{Na}^{+}, \mathrm{K}^{+}$ATPase inhibitors. Second, glutamine and certain neutral amino acids compete for dicarboxylic amino acid transport carrier (or carriers) sites, when at 40 times the concentration of dicarboxylic amino acid. Third, less than $10 \%$ of dicarboxylic amino acid uptake occurs either passively or through other amino acid transport systems.

Skin fibroblasts from patients with Friedreich's Ataxia seem to have a normal dicarboxylic amino acid uptake system which is less dependent on calcium for aspartic acid uptake and more dependent on phosphate and magnesium for Glu uptake in glucose-free medium. These figures could not be further explained without further investigation of glucose requirements of FA fibroblasts. Dicarboxylic aminoaciduria fibroblasts showed a reduced Vmax for aspartic acid and a number of other differences, including more sensitivity to metabolic inhibition and less dependence on calcium, sodium and temperature.

Passages in culture slowly reduced the effectiveness of aspartic acid uptake by control and FA fibroblasts but not by DCA fibroblasts. This observation suggests that the observed reduction in Asp uptake by DCA fibroblasts was not the result of cell aging or selection in culture. Hillman and Otto (1974) reported a reduced isoleucine uptake rate in a fibroblast line from a patient with $\alpha$-methyl acetoacetyl-Co A $\beta$-ketothiolase deficiency. Isoleucine uptake by the patient's cells was found to decrease with passage in culture until a stable culture was found in which sodiumdependent low concentration isoleucine uptake was lacking. Revsin and Morrow (1976) studied non-ketotic hyperglycinemia fibroblasts and reported lower Vmax for glycine uptake but not secondary to passages in culture.

In conclusion, we have shown that cultured skin fibroblasts from control, Friedreich's Ataxia, and dicarboxylic aminoaciduria patients have a group specific dicarboxylic amino acid uptake system with two unsaturable components. Kinetics, inhibition, and competition studies in all three cell lines revealed major differences from control and DCA fibroblasts with respect to Vmax, and ionic dependency in glucose-free medium only. Since the kinetic characteristics of the fibroblast's Glu uptake system are very similar to those reported for cultured astrocytes (Hertz et al., 1978) we assume that normal dicarboxylic amino acid uptake occurs in Friedreich's Ataxia glial cells also.

\section{ACKNOWLEDGEMENTS}

These studies were supported by grants from l'Association Canadienne de l'Ataxie de Friedreich, the Quebec Network of Medical Genetics (Ministère des Affaires Sociales) and the Medical Research Council of Canada. We thank Diane Leblanc, Ginette Trépanier, Robert Leblanc and Denise Collins for help in preparing the manuscript.

\section{REFERENCES}

AKEDA, T. and BRODY, T. M. (1969). The interaction between the chlorpromazine free radical and microsomal sodium - and potassium - activated adenosine triphosphatase from rat brain. Mol. Pharmacol. 5, 605-614.

BARBEAU, A. (1978). Friedreich's ataxia 1978-an overview. Can. J. Neurol. Sci., 5 , 161-165.

BOOTH, C. W. and NADLER, H. L. (1975). Neutral amino acid transport in cultivated human skin fibroblasts. Proc. Soc. Exp. Biol. Med. 148, 277-282.

BUTTER WORTH, R. F., HAMEL, E., LANDREVILLE, $F$. and BARBEAU, A. (1978a). Cerebellar ataxia produced by 3acetyl pyridine in rats. Can. J. Neurol. Sci. 5, 131-134.

BUTTER WORTH, R. F., HAMEL, E., LANDREVILLE, $F$. and BARBEAU, $A$ (1978b). Effect of alloxan diabetes on cerebellar amino acids. Can. J. Neurol. Sci. 5, 135-138.

CHESNEY, R.W., JAX, K.D., SCRIVER, C.R. and MOHYUDDIN, F. (1978). Taurine Transport in mammalian kidney. in Taurine and Neurological Disorders, A. Barbeau and R. Huxtable. Ed., Raven Press, New York, p. 73-93.

GRIFFIN, D. M. and SZEGO, C. M. (1968) Adenosine 3', 5'-monophosphate stimulation of uterine amino acid uptake in vitro. Life Sci., 7, 1017-1023. 
GROTH, V. and ROSENBERG, L. E. (1972). Transport of dibasic amino acids, cystine and trypophan by cultured human fibroblasts: Absence of a defect in cystinuria and Hartnup disease. J. Clin. Invest., 51, 21302142.

HERTZ, L., SCHOUSBOE, A., BOECHLER, N., MUKERJI, S. and FEDEROFF, S. (1978). Kinetic characteristics of the glutamate uptake into normal astrocytes in cultures. Neurochem. Res. 3, 1-14.

HILLMAN, R. E. and OTTO, E. F. (1974). Transport of L-isoleucine by cultured human fibroblasts. J. Biol. Chem. 249, 11:3430-3435.

HUXTABLE, R. and CHUBB, J. (1977). Adrenergic stimulation of taurine transport by the heart. Science, 28, 409-411.

JAYASHREE, C. and NAYEEMUNNIS, A. (1975). Neurochemical correlates of alloxan diabetes: brain aminotransferase heterogeneity in the rat. Life Sci., 17, 1159-1165.

KAYE, C. I. and NADLER, H. L. (1976). Transport of L-cystine by cultivated skin fibroblast of normal subjects and patients with cystinosis. Pediat. Res. 10, 637-641.

KILBERG, M. S. and NEUHAUS, $O$. W. (1977). Hormonal regulation of hepatic amino acid transport. J. Supramolecular Structure, 6, 191-204.

KINZIE, J. L., GRIMME, N. L. and ALPERS, D. H. (1976). Cyclic AMP-dependant amino acid uptake in intestine. Biochem. Pharmacol. 25, 2727-2731.

LEMIEUX, B., BARBEAU, A., BERONIADE, V., SHAPCOTT, D., BRETON, G. GEOFFROY, G. and MELANCCON, S. B. (1976). Amino acid metabolism in Friedreich's ataxia. Can. J. Neurol. Sci., 3, 373378.

LEMIEUX, B., GIGUERE, R., BARBEAU, A., MELANÇON, S. B. and SHAPCOTT, D. (1978). Taurine in cerebrospinal fluid in Friedreich's ataxia. Can. J. Neurol. Sci. 5, 125-130.
LOWRY, O. H., ROSEBROUGH, N. J., FARR, A. L. and RANDALL, R. J. (1951). Protein measurement with the folin phenol reagent. J. Biol. Chem. 93, 265-275.

MACDONALD, R. E., LANYI, J. K. and GREENE, R. V. (1977). Sodium-stimulated glutamate uptake in membrane vesicles of Escherichia coli: the role of ion gradients. Proc. Natl. Acad. Sci. USA, 74, 8:3167-3170.

MELANCON, S. B., DALLAIRE, L. LEMIEUX, B., ROBITAILLE, $P$. and POTIER, M. (1977). Dicarboxylic aminoaciduria: an inborn error of amino acid conservation. J. Ped. 91, 3:422-427.

MELANCON, S. B., GRENIER, B., DALLAIRE, L. and POTIER, M. (1978). Amino acid transport systems in cultivated human skin fibroblasts: Characterization of the dicarboxylic amino acid uptake system. Abstract, VII th. International Congress of nephrology, Montreal.

NOVOGRODSKY, A., TATE, S. T. and MEISTER, A. (1977). Uptake and utilization of L-glutamine by human lymphoid cells; relationship to $\gamma$-glutamyl transpeptidase activity. Biochem. Biophys. Res. Comm. 78, 1:222-229.

PELLEFIGUE, F., DEBROHUM BUTLER, J., SPIELBERG, S. P., HOLLENBERG, $M$. D., GOODMAN, S. I. and SCHULMAN, J. D. Normal amino acid uptake by cultured human fibroblasts does not require gammaglutamyl transpeptidase. Biochem. Biophys. Res. Comm. 73, 4:997-1002.

PERRY, T. L., APPLEGARTH, D. A., EVANS, M. E. and HANSEN, S. (1975). Metabolic studies of a family with massive formiminoglutamic aciduria. Pediatr. Res. 9, 117-122.

PERRY, T. L., STEDMAN, D. and HANSEN, S. (1968). A versatile lithium buffer elution system for single column automatic amino acid chromatography. Clin. Chim. Acta 38, 460-466.
PHANG, J. M., DOWNING, S. J. and WEISS, I. W. (1970). Cyclic AMP stimulation of amino acid uptake in bone and kidney. Biochim. Biophys. Acta 211, 605-608.

POSTE, G., PAPAHADJOPOULOS, D., JACOBSOND, K. and VAIL, W. J. (1975). Effects of local anesthetics on membrane properties. II. Enhancement of the susceptibility of mammalian cells to agglutination by plant lectins. Biochim. Biophys. Acta 394, 520-539.

REVSIN, B. and MORROW, G. (1976). Glycine transport in normal and non-ketotic hyperglycinemic human diploid fibroblasts. Exptl. Cell Res. 100, 95-103.

SAMUEL, A. M. and CAREY, M. D. (1978). Effect of chlorpromazine hydrochloride and its metabolites on $\mathrm{Mg}^{2}$ and $\mathrm{Na}^{+}, \mathrm{K}^{+}$ATPase activities of canalicular - enriched rat liver plasma membranes. Gastroenterology 74 , 1183-1190.

SCHOENFELD, N., EPSTEIN, $O$. and ATSMON, A. (1977). Inhibitory effect of membrane active compounds on the uptake of ${ }^{14} \mathrm{C}$ - $\alpha$-aminoisobutyric acid (AIB) in cultured chick embryo liver cells. Life Sci., 21, 329-334.

SEEMAN, P., KAWANT, W. O. and SANKS, T. (1969). Membrane expansion of erythrocyte ghosts by tranquilizers and anesthetics. Biochim. Biophys. Acta 183, 499-511.

TEWS, J. K., WOOKCOCK, N. A. and HARPER, A. E. (1970). Stimulation of amino acid transport in rat liver slices by epinephrine, glucagon and adenosine $3^{\prime}, 5^{\prime}$ monophosphate. J. Biol. Chem. 245, 30263032.

WEISS, I. W., MORGAN, K. and PHANG, J. M. (1972). Cyclic adenosine monophosphate stimulated transport of amino acids in kidney cortex. J. Biol. Chem. 247, 760-764. 